\title{
Improving health and well-being independently of GDP: dividends of greener and prosocial economies
}

Jules Pretty ${ }^{\mathrm{a} *}$, Jo Barton ${ }^{\mathrm{a}}$, Zareen Pervez Bharucha ${ }^{\mathrm{b}}$, Rachel Bragg ${ }^{\mathrm{a}}$, David Pencheon ${ }^{\mathrm{c}}$, Carly Wood ${ }^{\mathrm{a}}$ and Michael H. Depledge ${ }^{\mathrm{d}}$

${ }^{a}$ Department of Biological Sciences and Essex Sustainability Institute, University of Essex, Colchester, UK; ${ }^{b}$ Department of Sociology and Essex Sustainability Institute, University of Essex, Colchester, UK; ${ }^{c}$ Sustainable Development Unit for NHS England and Public Health England, Cambridge, UK; ${ }^{d}$ European Centre for Environment and Human Health, University of Exeter Medical School, Exeter, UK

(Received 25 September 2014; final version received 4 January 2015)

Increases in gross domestic product (GDP) beyond a threshold of basic needs do not lead to further increases in well-being. An explanation is that material consumption (MC) also results in negative health externalities. We assess how these externalities influence six factors critical for well-being: (i) healthy food; (ii) active body; (iii) healthy mind; (iv) community links; (v) contact with nature; and (vi) attachment to possessions. If environmentally sustainable consumption (ESC) were increasingly substituted for $\mathrm{MC}$, thus improving well-being and stocks of natural and social capital, and sustainable behaviours involving non-material consumption (SBs-NMC) became more prevalent, then well-being would increase regardless of levels of GDP. In the UK, the individualised annual health costs of negative consumption externalities (NCEs) currently amount to $£ 62$ billion for the National Health Service, and $£ 184$ billion for the economy (for mental ill-health, dementia, obesity, physical inactivity, diabetes, loneliness and cardiovascular disease). A dividend is available if substitution by ESC and SBs-NMC could limit the prevalence of these conditions.

Keywords: material consumption; green economies; sustainable behaviours; green exercise; health costs; well-being; obesity; mental health; loneliness; physical inactivity

\section{The gross domestic product (GDP) and well-being gap}

Increases in GDP beyond a threshold of basic needs do not necessarily lead to further increases in aggregate well-being (Jackson 2009; Royal Society 2012; Kubiszewski et al. 2013). Latitudinal analyses across many countries show the characteristic consumption cliff and affluent uplands shape: at low per capita GDP, well-being increases with rising GDP; after a threshold, well-being becomes less dependent on GDP across the affluent uplands (Pretty 2013). Longitudinal analyses further show that well-being in already affluent countries has remained stable over half a century even though per capita GDP has risen substantially (between threefold and eightfold in the UK, the USA and Japan) (Figure 1) (UNDP 2011; UNICEF 2012; Veenhoven 2012; World Bank 2012; Pretty 2013: data from UNCSD 2012; FAO 2014).

Despite the apparent lack of well-being dividend once countries have become affluent by GDP measures, consumption patterns in many less wealthy countries continue to

\footnotetext{
*Corresponding author. Email: jpretty@essex.ac.uk
} 


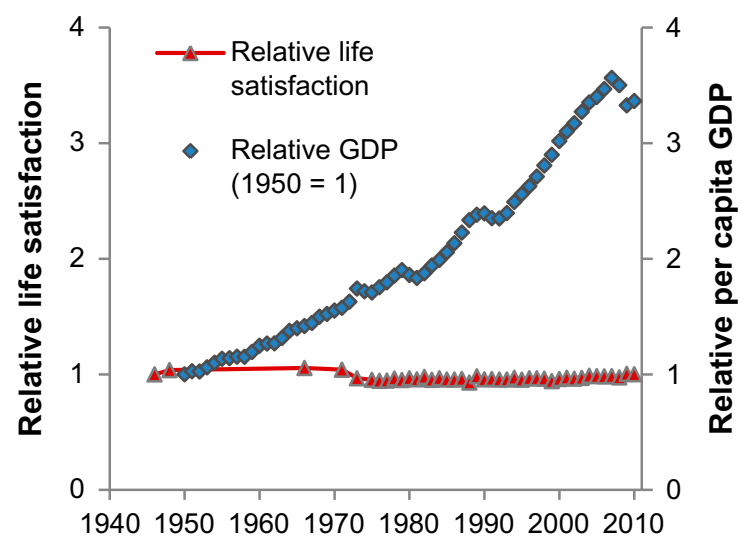

Figure 1. Changes in per capita GDP \& life satisfaction, UK (1946-2011) (Pretty 2013).

converge on those of the richest. As these countries follow similar paths, seeking to access source or sink natural resources in a similar fashion, so pressure on both natural and social systems grows (MEA 2005; NEA 2011; IPCC 2013; NCA 2014). A variety of global metrics demonstrate that planetary overshoot is occurring (Daly \& Cobb 1989; Rocktrom et al. 2009; WWF 2010; NEF 2013). The Royal Society (2012) has stated that indefinite growth is impossible in a finite world, yet conventional economic growth driven by escalating material consumption remains a primary goal. As a result, policy choices and practices that may build a greener economy and improve well-being and health have been displaced.

There is thus a growing interest in whether the concepts and practices that comprise a greener and more prosocial economy can address both social inequity and human well-being whilst reducing environmental risks and ecological scarcities (O'Neill et al. 2010; OECD 2011; UNEP 2011; Jacobs 2012; World Bank 2012; Kubiszewski et al. 2013; Böhm et al. 2014; Constanza et al. 2014). One priority is to redefine the concept of prosperity (McKibben 2007; Jackson 2009), and to encourage divergence in all types of consumption by individuals and countries, including substituting green goods and services, and prioritising non-material consumption behaviours (Pretty 2013).

Although well-being in affluent countries has on average not increased even though GDP has grown substantially, it is evident that material consumption has brought substantial improvements in medical technology, computer and mobile communications technologies, crime detection, better social and medical services, safer vehicles, better transport, more housing comfort and lately rapid adoption of renewable sources of energy production. Worldwide, mean life expectancy has risen from 56 to 69.6 years since the 1960s, driven strongly by a sharp fall in under-5 mortality rates from 153 to 51 per 1000 live births (UNICEF 2012).

Part of the explanation for the growing gap between rising GDP and stable wellbeing is that some types of consumption (and thus GDP) do lead to increases in wellbeing, but this is being eroded by costly negative externalities that depress health and well-being. For some countries, such as the UK, growth in GDP has resulted in a zero sum game. For poorer countries, this will not yet have been the case, as well-being improves sharply as GDP increases from low levels, supporting basic consumption needs for food, water, housing, education, security, health care and transport (Figure 2). 


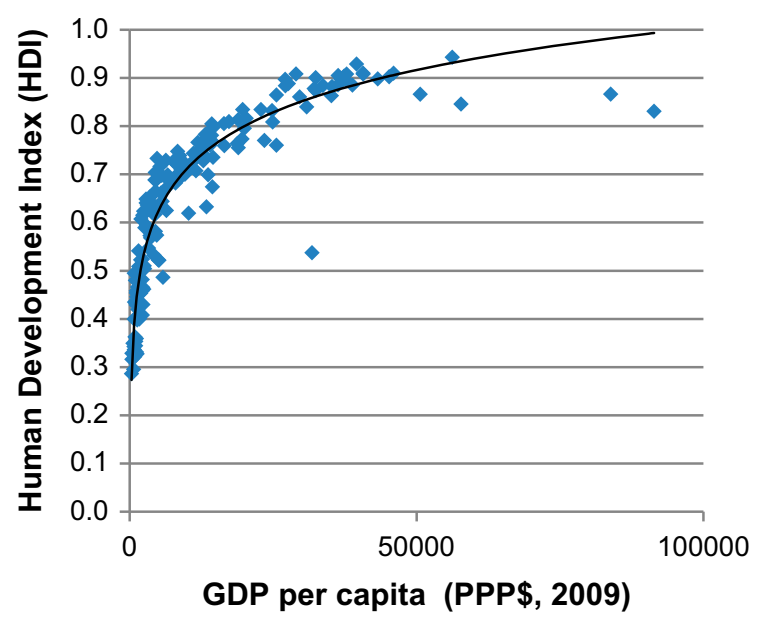

Figure 2. Relationship between GDP and HDI at country level $(n=173)$ (Pretty 2013).

Here we propose a model to characterise how consumer behaviour affects the choices and behaviours of individuals. It is widely assumed that material consumption (MC) positively affects well-being (Figure 3a). However, this same MC produces negative side effects that influence six factors critical for health and well-being (Layard 2006; Jackson 2009; NEA 2011; Jacobs 2012; Pencheon 2012; NEF 2013; Pretty 2013): (i) healthy food; (ii) active body; (iii) healthy mind; (iv) links with community and family; (v) contact with nature and green/blue space; and (vi) attachment to meaningful possessions (Table 1). As each of these is negatively affected, either separately or

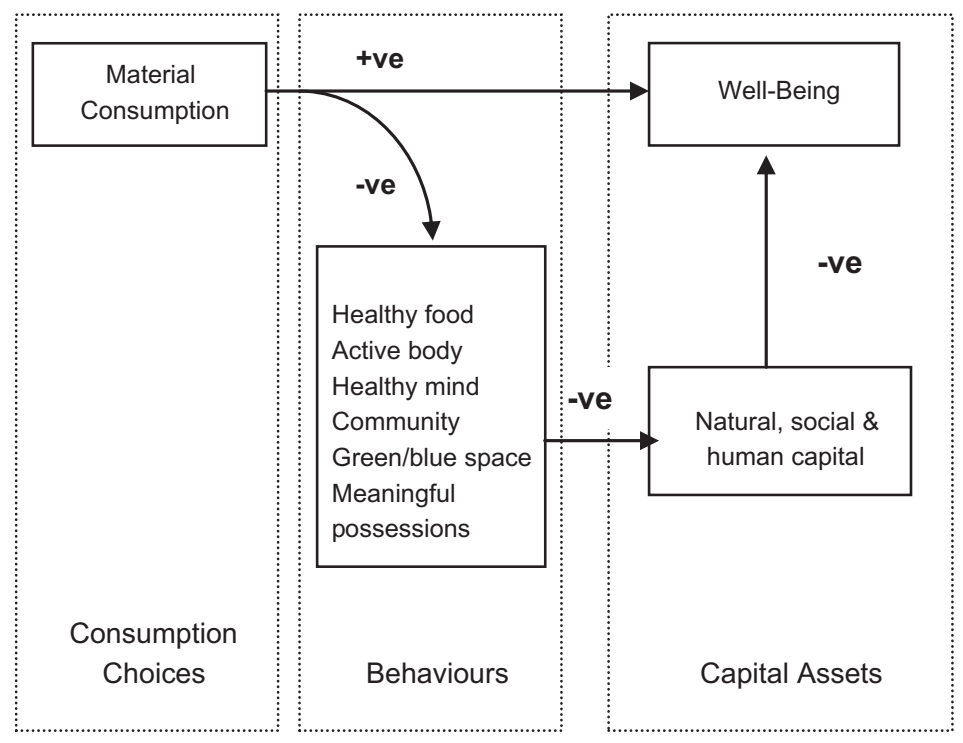

Figure 3a. The side effects of material consumption of goods and services and impacts on well-being. 


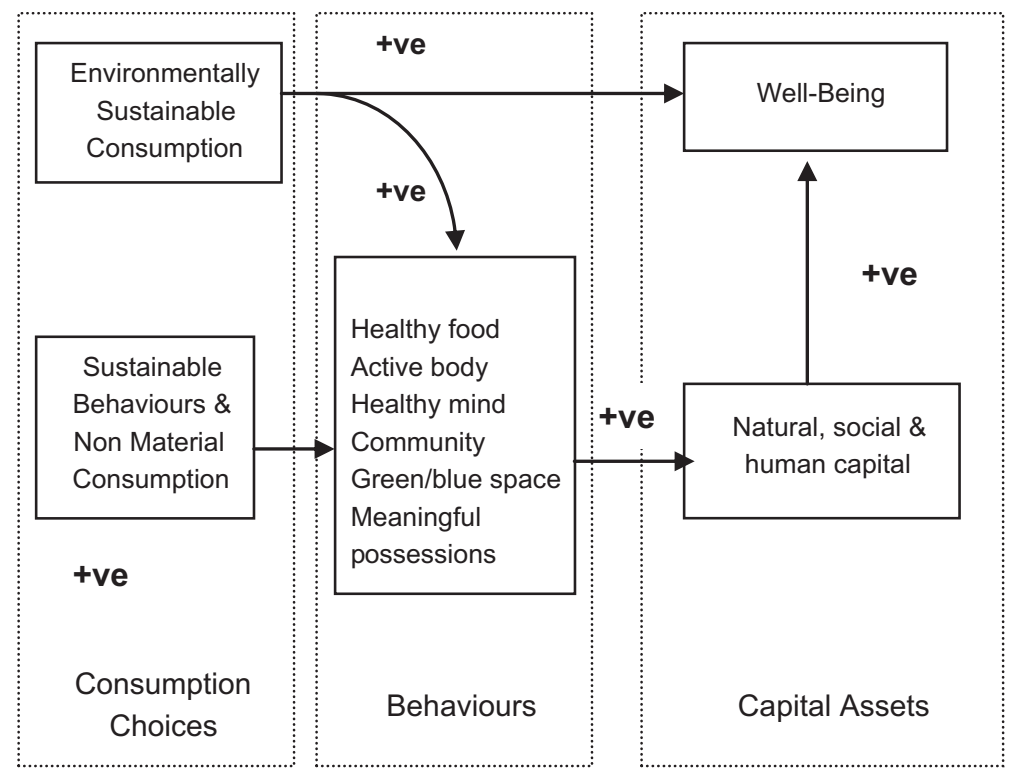

Figure $3 b$. The effect of both green material and non-material consumption on well-being.

in combination, so natural, social and human capital are eroded, and well-being itself declines.

Figure $3 \mathrm{~b}$ proposes a variant whereby environmentally sustainable consumption (ESC) substitutes for MC, thus improving well-being and stocks of renewable natural, social and human capital assets and sustainable behaviours involving non-material consumption (SBs-NMC) are substituted and sustained. SBs-NMC includes activities in nature (e.g. gardening, angling and walking) and in communities (e.g. volunteering, sports, meetings, community ceremonies and rituals). These are known to have direct benefits for individual well-being of both donors and recipients (Layard 2006; Barton \& Pretty 2010; NEF 2013).

Thus, increases in ESC and SBs-NMC that substitute for MC result in behaviours that build capital assets and improve well-being, whilst at the same time slowing the convergence of MC patterns towards high and unsustainable levels that threaten the integrity of planetary natural capital (Anderson \& Bows 2011; Pretty 2013). Table 1 summarises the key indicators we have selected to quantify negative consumption externalities (NCEs). Some negative movements have often been accompanied by positive progress (away from costs and towards benefits), and these are summarised as countertrends. For example, there is evidence in the UK of more social isolation and loneliness brought about by changing family and community structures; yet, at the same time, the rise in social media has increased online social connections. As the obesity crisis emerged, so has a concern for the sustainability of food and agriculture. We explore these relationships by assessing the recent changes in negative side effects of MC for each of these six behaviour choice factors critical for health and well-being. We use data primarily from the UK in order to bind our analysis within one exemplar case. There are any interactions and overlaps between the various sections, and thus Table 1 contains principal and illustrative examples for each of the six behaviour choices and their countertrends. 
Table 1. Indicators for the negative externalities of material consumption of goods and services and counter trends.

Factors critical to

health and well- Principal indicators of negative

being externalities Examples of countertrends

1. Healthy Food (i) Overweight and obesity rates in adults (i) Increasing interest in food and and children

(ii) Junk food and drink availability and consumption

(iii) Calories consumed per day in food and drink

(iv). Comorbidities of obesity (e.g. diabetes, hypertension and high cholesterol)

2. Active Body (i) Proportion of people meeting national guidance for physical activity

(ii) Activity in workplace or place of education (e.g. km travelled per day by car; $\mathrm{km}$ walked; trip length; and declining physical activity in schools)

(iii) Activity during non-work leisure

(iv) Travel to/from work and education (e.g. car use and children driven to school)

3. Healthy Mind (i) Proportion of population with mental ill-health status of TV chefs

(ii) Greater understanding of food sources and sustainability of agriculture

(iii) Increasing demand for allotments

(i) Continued participation in sports and active leisure

(ii) Increased walking for health groups

(iii) Increased individual and community gardening

(ii) Hours worked and impact on wellbeing

(iii) Engagement with religious and spiritual groups

(iv) SSRI drug prescriptions per year

4. Links with Family and Community

5. Contact with Green Space and Nature

6. Attachments to Meaningful Possessions (i) Family structures fractured (e.g. divorce rates; rise in single parent families and children in single parent families; rise in adults living alone; and rise in elderly living along and lonely)

(ii) Incidence of loneliness

(iii) Loss of local shops, pubs and other services

(iv) Rates of volunteering and sense of belonging in communities

(i) Engagement with nature and green space (e.g. day visit to countryside and seaside; time spent outdoors)

(ii) Changes to biodiversity in green spaces nature reserves and parks

(iii) Continued threat of air pollutants

(iv) Proportion of population within accessible distance of green space

(i) Possessions turnover, measured by waste disposed per year (i) Increasing availability of talking and walking therapies

(ii) Increased popularity of new religious and spiritual movements

(iii) Increased awareness of importance of mindfulness

(i) Increase in use of social media

(ii) Rise in cooperative groups

(iii) Continued voluntary contributions for blood and organ donations, and financial contributions to charities (iv) Continuation of local ceremonies and rituals that build social capital

(i) Number of gardens and allotments

(ii) Number of protected areas,

(iii) Increasing memberships of wildlife, green and heritage organisations

(iv) Paths and access routes

(i) Recycling rates

(ii) Investments in homes, gardens and vehicles to prolong life

(iii) Households with solar PV panels

(iv) Rise in swapping and freecycling through internet 


\section{Evidence for the impact of the negative consumption externalities on health and well-being}

\section{Healthy food}

The modern era has brought unprecedented increases in food availability in affluent countries, reductions in prices relative to other goods and a falling proportion of household income spent on food. Yet in largely solving hunger, affluent economies have now entered mass nutrition transitions (Popkin 1998; Lang \& Rayner 2012). In the mid1980 s, average incidence of adult obesity in the UK was $3 \%$ : a quarter century later, it had risen to $24 \%$ of adult men and $26 \%$ of adult women. By 2012, $16 \%$ of children were obese, and a further $14 \%$ overweight (CMO 2013): childhood obesity tracks into adulthood, and a $1 \%$ reduction in UK childhood incidence would prevent 50,000 adults from becoming obese (Wang et al. 2010). The rate of growth has been worse in the USA (CDC 2014; UCS 2014); now many wealthier groups within fast developing countries are engaged in a similar transition to overweight populations (Foresight 2011).

Incidence of obesity has risen in all age cohorts (Figure 4), yet official food consumption data record no significant change to mean calorie consumption over the past decade; it remains at about $2400 \mathrm{kcal}$ per day (Defra 2013). One factor is levels of physical activity; another is empty calories. In the UK, the per capita annual consumption of soft (soda) drinks is $97 \mathrm{~L}$ per year (by comparison: in the USA, it is $216 \mathrm{~L}$ and in France, it is $37 \mathrm{~L}$ ). At a mean of 400-500 calories per L, this amounts to the per capital consumption of 120 empty calories per day in the UK. Developing countries are now converging on these patterns. Mexico is now the highest consumer of sugar-rich soft drinks, and has seen a rapid growth in prevalence of obesity (Carolan 2013). In India, concern over the links between consumption of soft drinks and obesity and diabetes has led public health researchers to call for a tax to control their sale (Basu et al. 2014).

There is no evidence that food consumption has become healthier. Despite public health advice, the number of people eating five portions of fruit and vegetables per day has been resolutely stable: over the past decade, one in four people eat five portions per day and one in four people eat none at all (Defra 2013). This is in contrast to smoking, where policy changes and greater regulation have reduced smoking rates in adults from 27 to $21 \%$ since the mid-1990s (accompanied by a sharper fall in smoking amongst children).

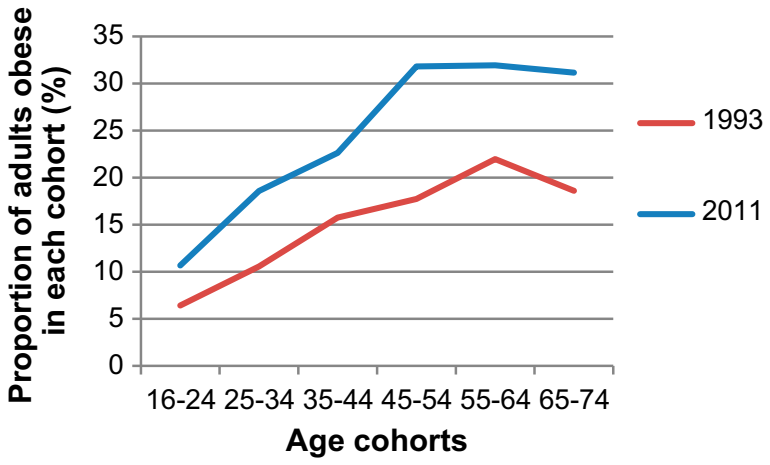

Figure 4. Proportion of UK adults obese by age cohort, 1993-2011. 
Both overweight and obese body status bring many comorbidities, in particular cardiovascular disease and type 2 diabetes. The incidence of doctor-diagnosed diabetes in the UK has increased since 1994 from 2.4 to $6 \%$ of adults. Incidence is greatest in the cohort older than 55 years of age, where it has more than doubled to affect one in six of $>75$-year-olds and one in ten of 55-64-year-olds. Life expectancy is reduced by 7-8 years by type 2 diabetes (Franco et al. 2007). The total health costs of obesity in the UK are rising, and are $£ 20$ billion per year (1.5\% of GDP of $£ 1.34$ trillion) (CMO 2013; PHE 2013a). Other environmental externalities of the food system, such as transport food miles (Pretty, Lang et al. 2005) are further drains on GDP ( $£ 1.5$ billion per year).

The increased access to cheap and energy-dense food in most industrialised countries is an important driver of ill-health. In all regions of the world, the proportion of consumed calories as fat has risen: up 32\% worldwide since 1961, in Europe $31 \%$, North America $11 \%$, Asia $71 \%$ and Africa only $5 \%$ (FAOStat 2014). The UK fast food market is worth $£ 11.4$ billion (2012), and comprises $23 \%$ of the out-of-home eating sector: sales have increased by $10 \%$ since the beginning of the recession in 2008 . There are 42,000 fast food and takeaway outlets in England, with an average of 78 per 100,000 people (PHE 2013a). The highest densities (up to 170 per 100,000) are in urban areas, and strong positive associations have recently been shown between an index of multiple deprivation and incidence of fast food outlets (PHE 2013a). There is some evidence from North America that higher rates of obesity occur in communities with high concentrations of fast food outlets (Smoyer-Tomic et al. 2008; Kwate et al. 2009). In the USA, life expectancy has fallen in many southern counties where there is both high-income inequality and high levels of obesity (Kulkarni et al. 2011).

\section{Countertrends}

The negative externalities of the food system are occurring despite an increasing interest in food cultivation and consumption. Food sources are better understood, and an increasing number of people demand food from sustainable sources and wish to grow or raise their own food (though this is limited to certain social groups). This, at least, reflects the re-emergence of an understanding that human health and well-being are dependent on the continued sustainability of ecosystems. Homegardens and allotments have long been important for domestic food production and consumption. In the midtwentieth century, half the UK workforce kept a vegetable garden, producing half of the nation's vegetable needs (Pretty 1998). In the UK, demand for allotments is increasing, with waiting lists at a 40-year high, having grown from 13,000 to 100,000 since the mid-1990s (NSALG 2009). In the USA, 35 million people grow their own food, the number of farmers' markets has grown from 340 in 1970 to 8000 in 2012, and the number of farm-to-school programmes grown from six in 2001 to 10,000 in 2012 (UCS 2014).

\section{Active body}

Physical activity improves both mental and physical health (CDC 1996; Foresight 2007; DoH 2009; Barton \& Pretty 2010; Thomspson-Coon et al. 2011; Newman \& Matan 2012); yet annually inactivity results in 1.9 million deaths worldwide (WHO 2004), and roughly 1 in 25 of all deaths. Individual energy expenditure has fallen dramatically over the past half-century (Davis et al. 2007). Inactivity increases the likelihood of obesity, and is a key risk factor in many chronic diseases of later life (Telema et al. 2005; Wichstrom 
et al. 2013). Individuals who do not engage in regular physical activity have a $20-30 \%$ increased risk of cardiovascular disease (CVD), which accounts for $39 \%$ of all deaths $(193,000$ per year) in the UK (Brown et al. 2014). Worldwide $80 \%$ of all CVD deaths are preventable (WHO 2010).

The term green exercise was coined to indicate the synergistic well-being benefits arising from activity in green places (Pretty, Peacock et al. 2005), and a dose of nature (Barton \& Pretty 2010) has been shown to have a positive effect on mental health for a wide range of activities (e.g. walking, angling, cycling and gardening), for all age groups, for every habitat (with additional benefits from the presence of water), and for the already healthy and the mentally-ill. Forest bathing (walking) in Japan reduces blood pressure and salivary cortisol, with greater benefits for the elderly and those already with high blood pressure and other stress markers (Lee et al. 2011; Horiuchi et al. 2013). Similar benefits have been identified for blue exercise (outdoor activities associated with the sea and other water bodies (Depledge \& Bird 2009; White et al. 2010). Ekblom-Bak et al. (2014) have used the term non-exercise physical activity (NEPA) to focus attention on the health benefits of daily activities such as home repairs, mowing the lawn, car maintenance, destination or errand-based bicycle rides, subsistence fishing and gathering wild foods: through positive surveillance they found that 60 -year old Swedish men and women with high NEPA had reduced risk of first time CVD by $27 \%$ and all-cause mortality by $30 \%$ over a 12.5 year period. There are thus three options for maintaining an active body: (i) activity at home or at the workplace/place of education; (ii) activity during non-work leisure (e.g. sports, gym and gardening); and (iii) active travel to and from work, education or leisure. Activity has declined in all these categories, and this decline is having a negative impact on well-being (Newman \& Matan 2012; DoT 2013).

Over the past four decades, there has been a gradual loss of non-motorised travel (walking and cycling), an increase in trip distance, and a rising proportion of the population travelling by car. Since the 1970s, the proportion of people holding a driving licence has risen from 48 to $73 \%$ (36 million), with the largest rise amongst women (up from 29 to $66 \%$ ). The mean number of all trips made per person has remained the same over the past 40 years, but average trip length has increased by $45 \%$ to 7 miles. In the 1970s, of the 954 trips per year, 300 were over less than a mile; today the number of such short trips has fallen to 190 (DoT 2013). Half of all trips are now made for work and education, $20 \%$ for shopping (increasing MC), and $30 \%$ for leisure and day visits (increasing both SBs-NMC and well-being) (DoT 2013). Urban sprawl is an important influence to active transport choices (Trubka et al. 2010; Jarrett et al. 2012).

On average Britons travel one hour daily, more than half of which is by car (DoT 2013). The mean time spent cycling over a year has not changed at $6 \mathrm{~h}$ per year, or 1 min per day, again insufficient to benefit health at either individual or population level. Walking has become less prevalent. Over the past 15 years, the number of walking trips per year has fallen from 292 to 222, and time devoted fallen $22 \%$ to $60 \mathrm{~h}$ (10 min per day). At average pace, 10 min covers approximately 0.4 mile or 1000 steps, only a tenth of the 10,000 steps or equivalent needed per day for good health (Tudor-Locke \& Bassett 2004). Children are also walking less: 0-16-year-olds walk 278 trips per year, down from 351. Over 1995-2012, the proportion walking to and from school has fallen from 47 to $42 \%$, with a rise in car travel from 29 to $35 \%$ (DoT 2013). A fifth of adults walk only once per year for $20 \mathrm{~min}$; a sixth of children never walk for this long (Table 2).

Location is an important modifier of choice for travel, with people living in cities taking more exercise (improving health), driving less (reducing MC), and using public 
Table 2. Indicators of active travel, UK (DoT 2013).

Indicators

Proportion of people $(\%)$

Proportion of adults walking for 20 min on 3 occasions per week 40

Proportion of adults walking for $20 \mathrm{~min}$ on 1 occasion per week 22

Proportion of adults walking for 20 min less than once per year $\quad 21$

$\begin{array}{ll}\text { Proportion of children never walking for } 20 \mathrm{~min} \text { at a time per year } & 17\end{array}$

Table 3. Mean individual travel by location (miles per year) (DoT 2013).

\begin{tabular}{lcc}
\hline Location & $\begin{array}{c}\text { Walking } \\
\text { (miles per person per year) }\end{array}$ & $\begin{array}{c}\text { Car/van } \\
\text { (miles per person per year) }\end{array}$ \\
\hline All UK & 184 & 5302 \\
London & 292 & 2431 \\
Rural locations & 122 & 8499 \\
Large urban $(>250,000$ population) & 206 & 4740 \\
Very small urban (3000-10,000) & 149 & 7089 \\
\hline
\end{tabular}

transport more (increasing ESC) (Table 3). In Manhattan, where people walk more and have easy access to public transport, obesity rates are $15.4 \%$ of adults, substantially less than the national average of $35 \%$ and NY state average of $24 \%$ (NY State Health Department 2014).

The costs of physical inactivity in the UK are $£ 8.2$ billion per year (DoH 2009; NICE 2009). All these costs could be eliminated. In the UK alone, some $23 \%$ of men and $26 \%$ of women are sedentary. In the USA, sedentary behaviour costs $\$ 90$ billion per year, and it is estimated that some 30,000 deaths could be prevented with adoption of regular physical activity (Brownson et al. 2005; Rutt \& Coleman 2005).

\section{Countertrends}

Participation in active leisure and sport is still widespread. There has also been an uptake in walking-for-health groups: 500 local schemes have 130,000 registered members, saving the NHS $£ 81$ million annually with regular participation (Natural England 2009). In 2013-2014, 15.6 million adults played sport at least once a week (1.7 million more than in 2005-2006), though $52 \%$ of adults play no sport at all (Sport England 2014).

\section{Healthy mind}

It has become clear that thought alone can cascade physiological pathways that influence well-being (Brefczynski-Lewis et al. 2007; Sternberg 2009). There are two important evidence bases: from research on contemplation arising from mindfulness and prayer, and from research on the placebo effect.

Many philosophical, spiritual and psychological traditions emphasise the importance of the quality of consciousness on well-being. Mindfulness emphasises attentiveness to the present, with focused awareness providing heightened sensitivity (Brown \& Ryan 2003), and therapeutic use has improved the well-being of patients with anxiety or persistent pain (Shapiro et al. 2008; Williams \& Penman 2011). Frequency of prayer experiences is a good predictor of well-being (Poloma \& Pendleton 1991), and there is 
evidence of value: the sending of prayer has no effect if the recipient does not know it is being practised; for those undertaking prayer, it improves their well-being (Benson et al. 2006). The combination of mindfulness with exercise improves well-being and produces stronger immune responses in practitioners (Sandlund \& Norlander 2000). Lutz et al. (2008) have shown that meditation cultivates positive emotions and improves empathy, and relaxation through meditation, prayer, yoga and tai chi are all associated with reduced blood pressure and heart rate, and increased serotonin and dopamine levels (Esch et al. 2003). Being in natural places encourages attentiveness and the ability to be mindful.

Recent research on the placebo effect (PE) has shown the potential benefits of "selfhealing" for some people. The placebo has long been conceptualised as an inert process, and thus used as an experimental control. The PE is now known to be a genuine phenomenon, with expectancy key in both patient and physicians/nurses (Finniss et al. 2010). The PE has yielded beneficial clinical results for angina, bronchial asthma, herpes, ulcers, inflammatory bowel syndrome, and persistent pain (Benedetti et al. 2005; Price et al. 2008; Zubieta \& Stohler 2009). Most research has been on analgesics, which has shown that the PE mechanism centres on the self-release of endogenous opioids. The PE has been shown to be blocked if opioid inhibitors, such as naloxone, are given to patients. Finniss et al. (2010) noted that alternative therapies with no agreed scientific explanation but with elaborate rituals can thus induce placebo effects, particularly if there is a good personal relationship between practitioner and patient. Kaptchuk et al. (2008) concluded that treatment augmented with warmth, attention and confidence improves clinical outcomes. Patients engage in treating themselves if physicians, nurses and carers have a friendly manner, engage in active listening, show empathy, allow periods of silence in conversation, and communicate confidence and positive expectations.

Affluent countries with high MC are often characterised by high levels of mental illhealth. Walker (2011) has observed that "our contemporary market system sells, more than anything else, discontent and unhappiness". In the past 15 years, prevalence of mental ill-health has been stable at $17 \%$ of the UK population. Prevalence is higher in children in lone parent families (16\% compared with $8 \%$ in two-parent families), and in families with lower educational achievements (17\% compared with $4 \%$ in families with higher education degrees) (CMO 2013). Mental health problems cost $£ 11-59,000$ per child per year: one in ten children under 16 years of age has a diagnosed mental disorder (CMO 2013).

There has been an associated increase in use of antidepressant drugs, with 47 million prescriptions for selective serotonin reuptake inhibitors (SSRIs) dispensed in 2011, up 4 million on the previous year (NHS 2012). There is some evidence to suggest that treatment by pill has become expected by many people (Mind 2007) rather than addressing more difficult behaviour change. However, SSRIs are effective for many sufferers of depression, and rises may partly be due to the increased recognition of depression and anxiety as serious and widespread conditions (Wijlaars et al. 2003; NHS 2012). In the USA, antidepressant use has grown fourfold since the mid-1980s, with $10 \%$ of the population aged 12 and over on antidepressant medication (Pratt et al. 2011). A separate drug problem has emerged in the USA, with a 20 -fold increase in use of methylphenidate (Ritalin) since the 1980s. The USA is responsible for $90 \%$ of worldwide consumption of Ritalin, and four million children and teens are administered the drug to control attention deficit hyperactivity disorder. The side effects are memory loss, drowsiness, insomnia and reduced physical activity. This may be contributing to increased incidence of overweight problems in children (Louv 2005). 
A factor in both GDP and well-being is long hours of work. Between 1991 and 2011, the average annual hours worked per employee fell in the OECD from 1850 to $1776 \mathrm{~h}$. In the UK, the fall was from 1716 to $1625 \mathrm{~h}$ per year. Hours worked are lowest in the Netherlands (1347) and Germany (1413), and highest in Korea (2193), Mexico (2250) and Chile (2047) (OECD 2013). Yet across OECD countries, shorter hours of work result in both higher GDP and higher life satisfaction (Figures 5a and 5b) (data from Veenhoven 2012; OECD 2013). Stress at work can disrupt cortisol profiles, which in turn provoke diabetes onset and increase breast cancer death rates (Hirschman et al. 2007; Rystedt et al. 2008): encouraging regular physical activity at work can have a positive effect on health (Brown et al. 2014).

As time spent in contemplation or prayer improves well-being, it is conceivable that a reduction in attendance at formal religious ceremonies may have had an influence on well-being. Church attendance has fallen dramatically in the UK: a half century ago, half the population attended church regularly. Today this has fallen to $7 \%$ of the UK

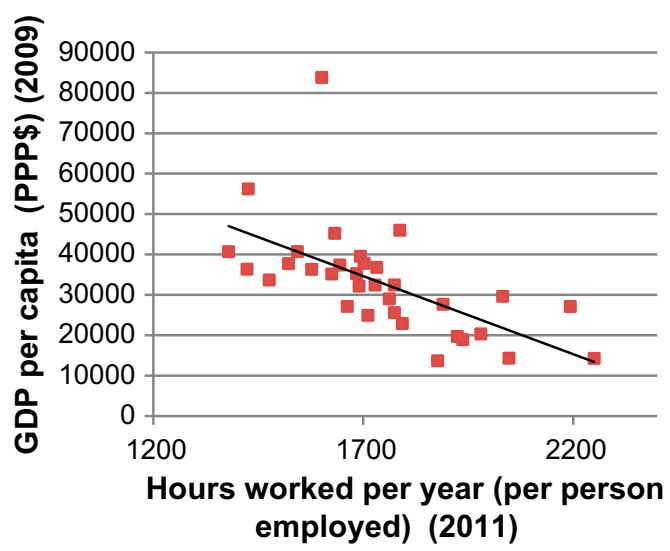

Figure 5a. Relationship between hours worked by employees and GDP (OECD countries).

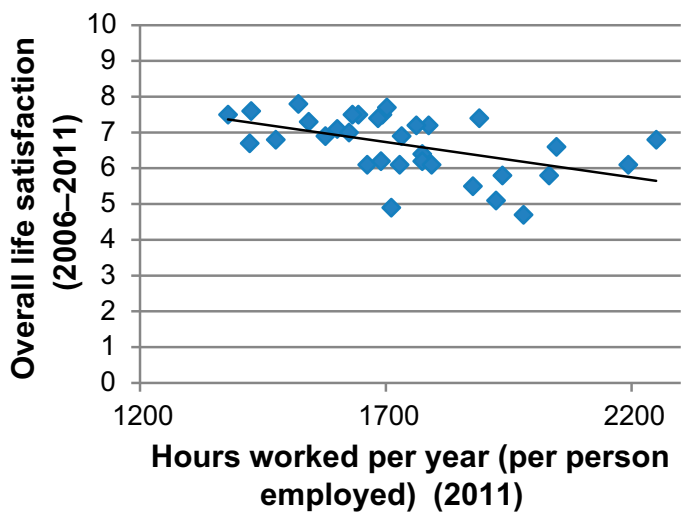

Figure 5b. Relationship between hours worked by employees and life satisfaction (OECD countries). 
population. Average age of attendees has risen since 1980 from the mid-30s to upper 50s. Total attendance (at least once monthly) at services connected to all religions has fallen since the mid-1980s from 21 to $15 \%$ (Tearfund 2007; British Attitudes Survey 2008). Between 2001 and 2011, the proportion of the population declaring themselves as having no religion rose from 15 to $29 \%$. The decline of spirituality and attendance at formal religious ceremonies has removed some opportunities for engagement with community and place, and may have negatively influenced well-being as well as reduced the capability to cope with stress. Modern society has become increasingly indifferent to spiritual traditions, especially in the public sphere (Walker 2011; Christie 2013): material culture appears to have filled the gap.

\section{Countertrends}

There is increased use of talking therapies, increased popularity of new spiritual and transition movements (Böhm et al. 2014), and growing use of green care. Green care is the use of structured therapeutic programmes using walking, gardening and/or farming, and has been successfully used for youth offenders, the self-declared mentally-ill (e.g. Mind members: Barton \& Pretty 2010), those suffering from dementias and post-traumatic stress (Hine et al. 2008; Mapes \& Hine 2011). In this way, attentiveness and mindfulness, outdoor activities and well-being can all be linked (Christie 2013). None as yet appear to have changed country-level incidence of mental ill-health.

\section{Links with community and family}

Insel and Young (2001) have observed: "it is difficult to think of any behavioural process that is more important to us than attachment". Attachment behaviour in humans has selective advantage and enduring bonds have been shown to have a neurohormonal basis (Strathearn et al. 2009). The neuropeptide, oxytocin, is the critical compound, and oxytocin receptors are concentrated in the dopamine-rich regions of the brain. Oxytocin is released by touching, by being in safe environments, and on receiving signals of trust from others. Subjects given oxytocin become more generous (Zak et al. 2007). Social attachment increases well-being; mothers with strong attachment to their infants show greater activation of brain reward regions, especially of the oxytocin-associated hypothalamus (Esch \& Stefano 2005).

Trusting relationships have a positive effect on health and well-being (Kawachi et al. 1997). The value attached to relationships has come to be known as social capital. This includes an individual's contacts and networks, the common rules, norms and sanctions that regulate behaviour, together with the reciprocity and exchanges that build friendships, respect and ultimately trust (Putnam 1995; Pretty 2003). Nature is good for health; green places can be good for social capital: people engage with the outdoors not just for the connection to nature, but to provide the setting for the building of social capital (Krenichyn 2004). Strong social support keeps the elderly alive: a meta-analysis found a $50 \%$ increased likelihood of survival over seven years for those people with strong relationships (Holt-Lunstad et al. 2010).

The lack of social attachment embodied by loneliness has a negative effect on health (Miller 2011). Lonely adults tend to have higher blood pressure, greater epinephrine secretion at night, higher morning and night-time cortisol levels, and poorer sleep patterns (Cacioppo et al. 2003; Hawkley \& Cacioppo 2007). Loneliness increases gene 
Table 4. Families structures in the UK, 1996-2012 (ONS, 2013).

\begin{tabular}{lccc}
\hline & $\begin{array}{c}\text { Number } \\
\text { (million) } 1996\end{array}$ & $\begin{array}{c}\text { Number } \\
\text { (million) } 2012\end{array}$ & $\begin{array}{c}\text { Proportional change } \\
\text { over 1996-2012 (\%) }\end{array}$ \\
\hline All families & 48.27 & 51.48 & $+6.6 \%$ \\
Married couples and civil partnerships & 38.02 & 35.80 & $-5.9 \%$ \\
Co-habiting couples & 3.93 & 8.02 & $+104.1 \%$ \\
Lone parent families & 6.32 & 7.63 & $+20.7 \%$ \\
Number of children in multi-person families & 28.78 & 28.44 & $-1.2 \%$ \\
Number of children in lone person families & 6.32 & 7.64 & $+20.9 \%$ \\
\hline
\end{tabular}

activity that promotes inflammation and with poorer sleep and reduced night-time repair, ill-health outcomes increase. Loneliness tracks into adulthood (though not all people alone are lonely), with lonely adults having had a greater number of childhood adversities such as hospitalisation, parental divorce and physical abuse (Asher \& Paquette 2003; Hawkley \& Cacioppo 2007). Shortened visits by carers may not help to remove loneliness; moreover, the chronic stress experienced by some carers themselves reduces immune response to vaccines and slows wound healing (Kiecolt-Glaser et al. 1996). Loneliness has the equivalent health risk as consuming 15 cigarettes daily and is twice as harmful as obesity (Bolton 2012).

An externality in countries with high material consumption is a greater fracturing of social bonds within families and communities. In the UK, $10 \%$ of over 65 -year-olds are always or very lonely (900,000 people), and half of 75-year-olds live alone (Campaign to End Loneliness 2013). Lonely people make more visits to general practitioner doctors (GPs) and attend Accident and Emergency at hospitals more often. Befriending, mentoring and gatekeeper services and group activities such as walking for health, have been shown to reduce hospital and health care costs, and after such interventions, mean visits to GPs fall from 10.8 to 6.7 per year (Pitkala et al. 2009; Windle et al. 2011).

In the UK, increased MC has coincided with changes to family structures, with more single parents, more loneliness, fewer family structures that support children, and a growing number of one person households (Table 4). The number of married couples and civil partnerships has fallen by 2.2 million, offset by the increase in number of co-habiting couples by more than 4 million. However, the number of lone parent families is up by 1.3 million to 7.6 million, and there are now 1.32 million more children in lone parent families. The number of people over 75 living alone has increased by 250,000 to 3.4 million.

\section{Countertrends}

People who contribute to community by volunteering to help others experience higher well-being (McCloughlan et al. 2011). Across the EU, 20\% of citizens participate in volunteering and charitable activities, the highest in Denmark, Finland and Sweden $(>45 \%$ ). Volunteering brings improved happiness, self-esteem, sense of control and better mental health (Thoits \& Hewitt 2001; Mellor et al. 2009). Those attending religious ceremonies are more likely to volunteer (McCloughlan et al. 2011). Volunteering thus helps to build social capital and improves well-being in both donors and recipients. A sense of belonging also increases well-being: $66 \%$ of all adults indicate a strong sense of belonging to their neighbourhood, rising amongst the elderly ( $>70$-year-olds) to $84 \%$. In the UK, only $17 \%$ of adults regularly volunteer in their community, rising to 
$22.5 \%$ of $>65$-year-olds. However, most data indicate levels of volunteering are far below levels necessary to have a widespread impact on well-being: $40 \%$ of adults engage in civic participation once per year and $71 \%$ in volunteering once per year (DCLG 2013).

Despite the declines in social capital in countries where MC has increased, prosocial behaviour continues in many contexts (Böhm et al. 2014). The emergence of social media has increased opportunities for social interaction, and thus reduced a sense of isolation for some. The formal cooperative movement is also growing: there are 5900 independent cooperative entities with 13.5 million members in health care, housing, farming, sports, credit unions and shops (Cooperatives UK 2010). In addition, there are many community-based enterprises, sports clubs, libraries, local repair shops, craft businesses, writing centres and community social groups that deliver social capital, belonging and well-being. At the same time, many people voluntarily donate blood and organs for the benefit of others, make financial contributions to charities and for disaster relief, and engage in local rituals and ceremonies that build social capital. Membership of wildlife, nature and heritage organisations continues to grow.

\section{Contact with nature and green/blue space}

The natural environment provides important ecosystem services that underpin economies (MEA 2005; NEA 2011; Fitter 2013). Ecosystems also provide health services (White et al. 2010; Pretty et al. 2011; Jackson et al. 2013) thorough direct positive effects on mental and physical health; indirect positive effects by facilitating nature-based activity and social engagement, and catalysing behavioural change towards healthier lifestyles; and reducing the threats to health arising from pollution and disease vectors (NEA 2011).

Direct health and well-being benefits arise from light, colour, whole views, bird song and scents (Pretty, Peacock, et al. 2005; Hunter et al. 2010; Ratcliffe et al. 2013). The view from the window enhances well-being and healing in hospitals and prisons (Moore 1982; Ulrich 1984), views with natural elements (trees, green space, blue sky and water) have a positive effect while those with urban structures are negative (Pretty, Peacock, et al. 2005; Gladwell et al. 2012), and nature-rich drives increase recovery from stress for commuters (Parsons et al. 1998). People in urban areas with plentiful tree cover and green space have a lower prevalence of asthma, improved mental well-being, reductions in stress, positive effects on birth outcomes, lower morbidity, reduced CVD risk, greater longevity of the elderly, positive effects on cognitive function, and healthier cortisol profiles (Takano et al. 2002; Hartig 2008; Mitchell \& Popham 2008; Maas et al. 2009; Barton \& Pretty 2010; Bratman et al. 2012; Ward-Thompson et al. 2012). Conversely, the loss of familiar green spaces and even individual trees, causes tangible distress, a syndrome labelled solastalgia (Albrecht 2005). Less green space typical of deprived communities produces higher stress and flattened cortisol profiles (indicating poorer capacity to recover from stress) (Roe et al. 2013) and increased incidence of obesity (Lachowycz \& Jones 2011). As discussed earlier, there is likely to be a neurohormonal basis for the health benefits of contact with nature.

Further direct health benefits arise from exposure to sunlight, which is important for vitamin D manufacture (Holick 2004; Kampman et al. 2007). Interestingly, when Wheeler et al. (2012) analysed small-area census data for the population of England $(n=48.2$ million), they found that good health is more prevalent the closer one lives to the coast. Consistent with similar analyses of green space accessibility, the positive 
effects of coastal proximity were greater amongst more socio-economically deprived communities. The effects seen may be due to opportunities for stress reduction and increased physical activity.

Natural England (2013) research has shown that the highest levels of happiness occur in people visiting the outdoors more than once per week, and in people who garden. Yet today, only 66 visits are made per person per year to the natural environment, with only a third of the population visiting outdoors more than once per week. The amount of contact children have with nature is declining, with less than $10 \%$ of children playing in natural places such as woodlands, countryside and heaths, compared with $40 \%$ of children 30-40 years ago (Natural England 2009). Children now wander less, discover less and are losing some important connections to nature and place (Louv 2005; Wells \& Lekies 2006). Reasons for less outdoor play include parental fear of crime and road traffic, loss of natural spaces and the attractions of indoor alternatives.

\section{Countertrends}

There remain many opportunities for active engagement with green spaces. There are 16 million gardens in the UK, with owners regularly spending time outdoors; angling is the most popular outdoor activity, with 5 million regular participants. The area of protected areas in the UK has increased since 1980 from $0.2 \mathrm{M}$ ha to $7.6 \mathrm{M}$ ha (of which $2.6 \mathrm{M}$ ha on land, and $5 \mathrm{M}$ ha at sea). The number of national nature reserves in England has grown to 224 covering $0.6 \%$ of total land area. These contribute more than $£ 9$ million to local economies, attracting 18 million visitors per year who spend an additional £21 million locally (Natural England 2013). Membership of wildlife and environmental organisations grows, such membership demonstrating a commitment to the values of the organisation, and in some cases will lead to increased direct engagement with nature and green spaces. There has also been increased designation of paths (e.g. national coastal path), and active maintenance of the UK's extensive footpath network (118,000 miles) (Natural England 2013).

\section{Attachment to meaningful possessions}

Consumer culture has increased the turnover of possessions, and may have undermined a sense of identity, thus reducing well-being (Tuan 1977; Belk 1988; Walker 2011). Affluent economies need disposal and replacement; they are centred on ephemerality. If people became more attached to both possessions and natural places, and thus did not purchase new goods or repair harm to ecosystems, then the economy would suffer; by contrast, the planet would benefit incrementally from each attachment. When possessions and places acquire a high degree of attachment for people, then they are less likely to be disposed of or damaged (Schultz-Kleine \& Baker 2004; Pretty 2013).

Cathexis is the process of charging an object, activity or place with emotional energy (Belk 1988), which in turn emerges from memory creation. Attachments are formed with specific material objects, evolve over time, emerge from experience and personal history, and are thus a form of self-expression (Schultz et al. 1989; Belk 1991). This in turn leads to greater well-being: cherished possessions and places with high affiliation value result in higher life satisfaction and well-being (Sherman \& Newman 1977; Christie 2013). This has been recognised in hospitals and care settings: patients and the elderly are viewed as more socially capable and less dependent by 
medical and care staff, if they display personal possessions in wards (Millard \& Smith 1981; Wapner et al. 1990). People with possessions are more in control, less helpless and more supported by staff.

People invest more in meaningful possessions and natural capital when either or both are cathected with emotional energy (Anderson 1996). The more strongly homeowners cathect their dwellings, the more frequently they invest in mowing grass, painting, cleaning and remodelling. When people are deprived of their valued possessions and places, their personal identity is harmed too (Albrecht 2005). Possessions linked to memorable past events help to verify that the event occurred, and emotions (good and bad) are fixers of memory. In this way, possessions and green places can be thought of as magical vessels (Belk 1991), carrying the power of expressing stories, values and memories that are tangible proof of life events (Basso 1996; Curasi et al. 2005).

Material consumption has increased the turnover of possessions and thus the amount of waste produced. Despite an increase in the proportion of waste recycled in the UK over the past 20 years, the per capita production of waste has increased from 428 to $466 \mathrm{~kg}$ per year (Figure 6).

\section{Countertrends}

Despite the increased production of waste by the UK's material economy, individuals have increased recycling rates. The comfort of homes has increased with more central heating. Many people make investments in homes and vehicles, thus prolonging the length of time they are useful. More energy is generated nationally from renewables, yet is small, having risen from $0.6 \%$ in 1990 to $3.2 \%$ in 2011 (ONS 2013). However, there has been a dramatic increase in individual households with installed solar photovoltaics since the introduction of financial incentives: rising from 5000 in 2008 to 500,000 in 2014. This represents an increased investment of personal capital in green material consumption, with some benefits for natural capital. It may also reduce the turnover in houses, thus increasing belonging to neighbourhoods.

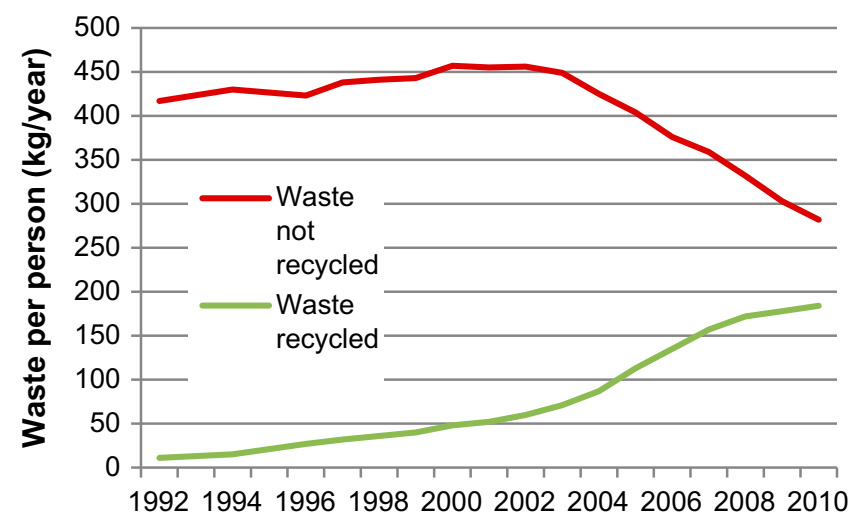

Figure 6. Waste production and proportion recycled, UK (1992-2010). 


\section{The health dividends of environmentally sustainable consumption (ESC) and sustainable behaviours involving non-material consumption (SBs-NMC)}

It has long been assumed that increased material consumption and rising GDP inevitably leads to increased well-being. Now a priority is to substitute activities that increase both ESC and SBs-NMC. Green growth and the green economy have become important targets for the OECD (2011), UNEP (2011), World Bank (2012), Rio +20 conference (UNCSD 2012) and the Global Green Growth Institute (2012). UNEP (2011) defines a green economy as "resulting in human well-being and social equity, while significantly reducing environmental risks and ecological scarcities".

We have indicated that the GDP: well-being gap has been partly caused by the negative externalities of material consumption (MC). Aggregated together, the benefits of $\mathrm{MC}$ and the countertrends we describe should have delivered considerable improvements to aggregate well-being. Yet, measured as life satisfaction at the population level, they have not. At the global level, the iron cage of arithmetic is stark: increasing convergence by poorer and developing countries on patterns of high MC typically prevalent in affluent countries will put further pressure on global natural capital (Pretty 2013). Substitution of MC by both ESC and SBs-NMC is becoming increasingly urgent, implying the need for green technology development and widespread behaviour change, supported by policies, new forms of social organisation and regulations that incentivise rapid uptake.

The evidence for successful interventions is, however, limited: more often than not advances towards ESC (e.g. more sustainable agriculture, greater energy efficiency in industrial processes, greater renewable energy production, increased material recycling and reuse, adoption of non-ozone damaging refrigerants) has been overtaken by increases in the number of people consuming and their expanding levels of consumption. In affluent countries, some policies and regulations have shifted individual behaviours towards greater well-being, but generally these again have been limited in number (e.g. shift to non-leaded petrol, restrictions on public and private locations where smoking is permitted), or affect only small subsets of the population (e.g. recommendations for physical activity, daily consumption of fruit and vegetables).

The ONS (2013) is now measuring well-being at the national level in the UK; but these measures have not yet changed policy or practice, particularly in health and social care. Mitchell and Popham (2008) concluded that "environments that promote good health might be crucial in the fight to reduce health inequalities". There is growing evidence showing that choices and behaviours at the individual level can make significant contributions to well-being, regardless of technological and policy progress to support shifts from MC to ESC. Such activities that result in greater well-being, substitute for $\mathrm{MC}$, and result in benefits for $\mathrm{NC}$ and SC include gardening, walking and running, nature watching and visiting, spiritual contemplation and social prayer, fishing, organised sports, volunteering, joining societies and clubs, playing music, engaging in art and writing.

This suggests a key dilemma: reducing MC to save the planet undermines an economy founded on continuing consumption; yet continuing $\mathrm{MC}$ at current rates to sustain the economy destroys the planet. Yet, a substantial financial dividend could be released by a greener and healthier economy (Terrapin Bright Green 2012; Beatley \& Newman 2013) centred on healthy food, regular engagement with nature, regular physical activity, the use of the power of thought and contemplation, the enhancement of social bonds, and increased attachment to possessions and places. Table 5 summarises the 
Table 5. The costs of the health externalities arising from modern lifestyles in the UK.

\begin{tabular}{|c|c|c|c|c|}
\hline Condition & $\begin{array}{l}\text { Proportion of } \\
\text { population affected }\end{array}$ & $\begin{array}{l}\text { Number } \\
\text { affected }\end{array}$ & $\begin{array}{l}\text { Annual cost } \\
\text { to NHS } \\
\text { (£ billion) })^{3}\end{array}$ & $\begin{array}{l}\text { Full annual } \\
\text { cost to economy } \\
\text { (£ billion) })^{4}\end{array}$ \\
\hline Mental ill-health & $\begin{array}{l}17.6 \% \text { of adults } \\
10 \% \text { of children }\end{array}$ & 8.8 million & $£ 21.0$ & $£ 105.0$ \\
\hline Dementias & $\begin{array}{l}13 \% \text { of }>65 \text { year } \\
\text { olds }\end{array}$ & 0.75 million & $£ 20.0$ & $£ 20.0$ \\
\hline Obesity $^{1}$ & $\begin{array}{l}26 \% \text { of adults } \\
15 \% \text { of children }\end{array}$ & $\begin{array}{l}13 \text { million adults } \\
1.9 \text { million } \\
\text { children }\end{array}$ & $£ 5.0$ & $£ 20.0$ \\
\hline $\begin{array}{l}\text { Physical } \\
\text { inactivity }^{2}\end{array}$ & $\begin{array}{l}20 \% \text { of adults } \\
\text { completely inactive }\end{array}$ & 10 million adults & $£ 1.8$ & $£ 8.2$ \\
\hline $\begin{array}{l}\text { Diabetes } \\
\quad \text { (type 2) }\end{array}$ & $4.5 \%$ of adults & 2.9 million & $£ 13.75$ & $£ 29.0$ \\
\hline Loneliness & $\begin{array}{l}30 \% \text { of }>65 \text { year } \\
\text { olds }\end{array}$ & 0.9 million & $£ 10.0$ & $£ 40.0$ \\
\hline $\begin{array}{l}\text { Cardio-vascular } \\
\text { disease } \\
\text { (including } \\
\text { hypertension } \\
\text { and strokes) }\end{array}$ & & $\begin{array}{l}1.84 \text { million in- } \\
\text { patient episodes } \\
\text { (of which } 0.24 \\
\text { million for } \\
\text { strokes): } \\
180,000 \text { deaths }\end{array}$ & $\begin{array}{l}£ 10.5 \text { (of which } \\
£ 1.8 \text { for strokes) }\end{array}$ & $£ 22.6$ \\
\hline $\begin{array}{l}\text { Total (assuming } \\
\text { all costs } \\
\text { independent } \\
\text { and additive. }\end{array}$ & & & $£ 82.1$ & $£ 244.8$ \\
\hline $\begin{array}{l}\text { Total costs } \\
\quad \text { (assuming one } \\
\text { quarter of costs } \\
\text { double-counted }\end{array}$ & & & $£ 61.5$ & $£ 183.6$ \\
\hline
\end{tabular}

Notes: ${ }^{1}$ Obesity costs are assumed to be the same for adults and children. The annual health costs of obesity in the USA are $\$ 147$ billion, equivalent to $\$ 1429$ per treated person (CDC 2014).

${ }^{2}$ We have not calculated the individual costs of physical inactivity as most are manifested in other co-morbidities (e.g. obesity, diabetes).

${ }^{3}$ The annual NHS costs per person with each condition are as follows: $£ 2390$ for mental ill-health; $£ 26,700$ for dementia; $£ 384$ for obesity; $£ 4741$ for diabetes; $£ 768$ for loneliness; and between $£ 5437$ and $£ 7500$ for CVD.

${ }^{4}$ The full annual costs per person with each condition are as follows: $£ 11,900$ for mental ill-health; $£ 1538$ for obesity; $£ 10,000$ for diabetes; $£ 3072$ for loneliness; and $£ 11,812$ for CVD.

Sources: Foresight (2008); NHS (2010); Mental Health Network (2011); Kanavos et al. (2012); CMO (2013); PHE (2013b); O’Donnell et al. (2014).

costs of the health externalities arising from modern lifestyles in the UK. The annual direct cost of mental ill-health, dementias, obesity, physical inactivity, diabetes, loneliness and cardiovascular disease (including strokes) is $£ 82$ billion; the full cost to the whole economy is approximately $£ 250$ billion annually (18.6\% of GDP). The revenue expenditure of the 248 NHS Trusts in 2011-2012 was £102 billion (DoH 2013).

As we have shown in the review of evidence of impact on health, there are many possible interactions between causes and outcomes. Mental ill-health will have direct costs and consequences; it may also lead to reductions in physical activity, which in turn could influence caloric intake. Loneliness could have an impact on onset of dementias. The individual costs of each of the seven conditions in Table 5 thus will include some of costs for treatment for other conditions. Nonetheless, some costs have been allocated according to the presentation of a condition to the health service (e.g. CVD and 
diabetes), and these are real costs to the service providers. Others costs, such as of loneliness, are calculated from combinations of drivers. We thus assume a cautious reduction of costs by $25 \%$ to account for interactive effects and co-morbidities.

This implies there are health savings to be made if prevalence of these conditions and recruitment to medical treatment is reduced. Upstream activities and behaviours that prevent these negative health externalities improve the well-being of individuals and result in reduced costs to both the health service and economy at large. The Chief Medical Officer (2013) suggests that the health costs of lifestyles and behaviours comprise a "new canon for prevention". With an ageing population, cost inflation and pressures on revenue, the UK's National Health Service as a system needs to find ways to invest in prevention rather than wait until it has to treat conditions. Table 5 shows that the annual health and social costs per individual, and thus the savings for each avoided condition, vary between $£ 500$ and 12,000 , though are higher for dementias.

The cost of a single in-patient stay for an obese person is $£ 3215$; the average cost per accident and emergency presentation is £108; the average cost of a CVD hospital admission $£ 4614$ (DoH 2013). The benefits to the NHS of programmes that prevent recruitment are thus relatively small per person, but aggregated up very quickly at population level, suggesting that investments in healthy lifestyle programmes would bring many benefits. Befriending programmes for the elderly-lonely reduce the annual number of GP visits from 10.8 to 6.7 , saving $£ 195$ per person; walking for health programmes produce $£ 623$ of benefits per person annually; mentally-ill patients accessing CBT and chronic disease management save $£ 2000$ per person (MNH 2012).

The Chief Medical Officer (2013) has estimated that there is a $6-10 \%$ annual rate of return on investments made in early life interventions. The costs of one year in a children's residential home are $£ 149,000$, of one admission to in-patient mental health services $£ 25,000$; the long-term costs of child obesity are approximately $£ 600$ million, the annual short-term costs of emotional, conduct and hyperkinetic disorders in children some $£ 1.5$ billion. A half of all adult mental illness begins before the age of 15 , and $75 \%$ before the age of 18 (Foresight 2008; CMO 2013). Mental health problems track into adulthood, just as overweight and obesity do (Knapp et al. 2011).

In the USA, the Union of Concerned Scientists (2014) has indicated that a third (750,000 people) of fatalities are attributable to CVD, causing direct annual medical costs of $\$ 273$ billion. The average American consumes just 0.8 portions of fruit and 1.6 portions of vegetables daily (USDA ERS 2013); each additional daily fruit and vegetable portion reduces the risk of stroke and CHD by $4-5 \%$ (Dauchet et al. 2006). One additional portion consumed daily would prevent 30,000 deaths; consumption at recommended levels would prevent 127,000 deaths (calculated to have $\$ 11$ trillion of present value arising from longevity and better lives).

The UK government's public health strategy, Healthy Lives, Healthy People (DoH 2011), explicitly recognises that health considerations are an important part of planning policy. The National Planning Policy Framework (DCLG 2012) further makes it clear that local planning authorities have a responsibility to promote healthy communities, and a number of local authorities have drawn up supplementary planning documents (SPDs) that seek to limit the number of fast food outlets in close proximity to schools. The challenge is to create a built environment that is "sociable and green" (O'Donnell et al. 2014). The UK Public Services (Social Value Act) 2012 "requires public authorities to have regard to economic, social and environmental well-being".

A greener economy that emphasises ecological public health (Frumkin 2005; Lang \& Rayner 2012) would be one in which attention is paid to the environmental and 
social context of the public not yet ill, patients and all professionals and families engaged in treatment and care (Pencheon 2012; CMO 2013). The Marmot Review (2008) of health inequalities concluded that "economic growth is not the most important measure of our country's success", and prioritised the accumulation of the positive effects on well-being across the whole life course by building social capital, encouraging active travel, use of public transport, availability of green space and healthy eating, and promotion of nature-based interventions for health. Public Health England (2013) has observed that there is a need to find ways "to walk out of necessity", not choice. Some structures and policies are being established: the challenge of widespread adherence to behaviour change remains, as does the wider narrative about the benefits of greener and prosocial economies.

\section{Conclusions}

Our scorecard for the six sustainable lifestyle and behavioural choices that contribute to greener and more prosocial economies is mixed. Most appear to be in substantial deficit, suggesting an opportunity for health and financial benefits through action and policy. The total costs of the seven major conditions associated with modern material consumption lifestyles (mental ill-health, dementias, obesity, physical inactivity, diabetes, loneliness and CVD) are $£ 62$ billion annually to the NHS, and $£ 184$ billion to the whole economy. As environmental and social context influences well-being and health, positive policies to shape economies and societies for individuals will increase the likelihood that more people will be able to live their lives well and for longer. A greener, healthier economy would prioritise choices for both ESC over MC and SBs-NMC over MC, thus resulting in well-being benefits for individuals, and co-benefits for natural capital and finite Earth.

\section{Acknowledgements}

This research was funded by the time allocated by staff at the University of Essex, University of Exeter and NHS Sustainable Development Unit. We are grateful for the helpful comments and suggestions of two anonymous referees.

\section{References}

Albrecht GA. 2005. Solastalgia: a new concept in human health and identity. Philoso Activism, Nat. 3:41-55.

Anderson E. 1996. Ecologies of the heart. New York (NY): Oxford University Press.

Anderson K, Bows A. 2011. Beyond "dangerous" climate change: emission scenarios for a new world. Phil Trans R Soc A. 369:20-44.

Asher SR, Paquette JA. 2003. Loneliness and peer relations in childhood. Curr Dir Psychol Sci. 12:75-78.

Barton J, Pretty J. 2010. What is the best dose of nature and green exercise for mental health? A meta-study analysis. Environ Sci Technol. 44:3947-3955.

Basso K. 1996. Wisdom sits in places: landscape and language among the Western Apache. Albuquerque, (NM): University of New Mexico Press.

Basu S, Vellakkal S, Agrawal S, Stuckler D, Popkin B, Ebrahim J. 2014. Averting obesity and type 2 diabetes in India through sugar-sweetened beverage taxation: an economic-epidemiologic modeling study. PLoS Med. 11:e1001582.

Beatley T, Newman P. 2013. Biophilic cities are sustainable, resilient cities. Sustainability. 5:3328-3345.

Belk RW. 1991. Possessions and the sense of the past. In: Belk RW, editor. Highways and buyways. Association for Consumer Research: Duluth (MN). 
Belk RW. 1988. Possessions and the extended self. J Consumer Res. 15:139-168.

Benedetti F, Mayberg HS, Wager TD, Stohler C, Sand Zubieta J-K. 2005. Neurobiological mechanisms of the placebo effect. J Neurosci. 25:10390-10402.

Benson H, Dusek JA, Sherwood JB, Lam P, Bethea CF, Carpenter W, Levitsky S, Hill PC, Clem DW, Jain MK, Drumel D, Kopecky SL, Mueller PS, Marek D, Rollins S, Hibberd PL. 2006. Study of the therapeutic effects of intercessory prayer (STEP) in cardiac bypass patients: a multicenter randomized trial of uncertainty and certainty of receiving intercessory prayer. Am Heart J. 151:934-942.

Böhm S, Bharucha ZP, Pretty J. 2014. Ecocultures: Blueprints for Sustainable Communities. London: Routledge/Earthscan.

Bolton M. 2012. Loneliness - the state we're in. London: Campaign to End Loneliness.

Bratman GN, Hamilton JP, Daily GC. 2012. The impacts of nature experience on human cognitive function and mental health. Ann NY Acad Sci. 1249:118-136.

Brefczynski-Lewis JA, Lutz A, Schaefer HS, Levinson DB, Davidson RJ. 2007. Neural correlates of attentional expertise in long-term meditation practitioners. P Natl Acad Sci. 104:11483-11488.

British Attitudes Survey. 2008. Available from: http://www.natcen.ac.uk/our-research/research/brit ish-social-attitudes/

Brown DK, Barton JL, Pretty J, Gladwell VF. 2014. Walks4Work: assessing the role of the natural environment in a workplace physical activity intervention. Scand J Work Environ Health. 40:390-399.

Brown KW, Ryan RM. 2003. The benefits of being present: mindfulness and its role in psychological well-being. J Person Soc Psychol. 84:822-848.

Brownson RC, Boehmer TK, Luke DA. 2005. Declining rates of physical activity in the united states: what are the contributors? Annu Rev Publ Health. 26:421-443.

Cacioppo JT, Hawkley LC, Berntson GG. 2003. The anatomy of loneliness. Curr Dir Psychol Sci. 12:71-74.

Campaign to End Loneliness. 2013. Available from: http://www.campaigntoendloneliness.org/

Carolan MS. 2013. Reclaiming food security. Oxon: Routledge.

[CDC] Centres for Disease Control and Prevention. 1996. Physical activity and health. A Report of the Surgeon General. Washington (DC).

[CDC] Centres for Disease Control and Prevention. 2014. Obesity facts. Available from: www. cdc.gov.

Christie DE. 2013. The blue sapphire of the mind. New York (NY): Oxford University Press.

[CMO] Chief Medical Officer. 2013. Chief Medical Officer's Annual Report 2012: Our Children Deserve Better: Prevention Pays. London: UK Government.

Cooperatives UK. 2010. The UK Cooperative Economy. Manchester (UK): Cooperatives UK.

Constanza R, de Groot R, Sutton P, van der Ploeg S, Kubiszewski I, Farber S, Turner RK. 2014. Changes in the global value of ecosystem services. Global Environ Change. 26:152-158.

Curasi CF, Price LL, Arnould EJ. 2005. How individuals' cherished possessions become families' inalienable wealth. J Consumer Res. 31:609-622.

Daly HE, Cobb C. 1989. For the common good. Boston, MA: Beacon Press.

Davis A, Valsecchi C, Fergusson M. 2007. Unfit for purpose: how car use fuels climate change and obesity. London (UK): IEEP.

Dauchet L, Amouyel P, Dallongeville J. 2006. Fruit and vegetable consumption and risk of stroke: a meta-analysis of cohort studies. Neurology. 65:1193-1197.

DCLG. 2012. National planning policy framework. London: Department for Communities and Local Government.

DCLG. 2013. Citizenship survey. London: Department for Communities and Local Government and Cabinet Office.

Defra. 2013. National environment indicators. London: Department for Environment, Food and Rural Affairs.

Depledge MH, Bird W. 2009. The blue gym: health and wellbeing from our coasts. Mar Pollut Bull. 58:947-948.

DoH. 2009. Be active and healthy. A plan for getting the nation moving. London: Department for Health

DoH. 2011. Healthy lives, healthy people. London: Department for Health.

DoH. 2013. NHS reference costs 2012-2013. London (UK): DoH. 
DoT. 2013. National travel survey. London: Department of Transport.

Ekblom-Bak E, Ekblom B, Vikstrom M, du Faire U, Hellenius ML. 2014. The importance of non-exercise physical activity for cardiovascular health and longevity. Brit J Sport Med. 48:233-238.

Esch T, Stefano GB. 2005. Love promotes health. Neuro Endocrinol Lett. 26:264-267.

Esch T, Fricchione GL, Stefano GB. 2003. The therapeutic use of the relaxation response in stress-related diseases. Med Sci Monit. 9:RA23-34.

FAO. 2014. FAOSTAT. Rome: Food and Agriculture Organisation.

Finniss DG, Kaptchuk TJ, Miller F, Benedetti F. 2010. Biological, clinical, and ethical advances of placebo effects. The Lancet. 375:686-695.

Fitter A. 2013. Are ecosystem services replaceable by technology? Environ Res Econ. 55:513-524.

Foresight. 2007. Tackling obesities: future choices. London (UK): Government Office of Science.

Foresight. 2008. Mental health - future challenge. London (UK): Government Office of Science.

Foresight. 2011. Global food and farming futures. London (UK): Government Office of Science.

Franco O, Steyerberg EW, Hu FB, Mackenbach J, Nusselder W. 2007. Associations of diabetes mellitus with total life expectancy and life expectancy with and without cardiovascular Disease. Arch Intern Med. 167:1145-1151.

Frumkin H. 2005. Health, equity and the built environment. Environ Health Persp. 113:290-291.

Gladwell VF, Brown DK, Barton JL, Tarvainen MP, Kuoppa P, Pretty J, Suddaby JM, Sandercock GRH. 2012. The effects of views of nature on autonomic control. Eur J Appl Physiol. 112: 3379-3386.

Global Green Growth Institute. 2012. Available from: www.gggi.org

Hartig T. 2008. Green space, psychological restoration, and health inequality. The Lancet. 372:1614-1615.

Hawkley LC, Cacioppo JT. 2007. Aging and loneliness: downhill quickly? Curr Dir Psychol Sci. 16:187-191.

Hine R, Peacock J, Pretty J. 2008. Care farming in the UK: contexts, benefits and links with therapeutic communities. Int J Ther Communities. 29:245-260.

Hirschman J, Whitman S, Ansell D. 2007. The black:white disparity in breast cancer mortality: the example of Chicago. Cancer Causes Control. 18:323-333.

Holick MF. 2004. Sunlight and vitamin D for bone health and prevention of autoimmune diseases, cancers and cardiovascular disease. Am J Clin Nutr. 80:1678S-88S.

Holt-Lunstad J, Smith TB, Layton JB. 2010. Social relationships and mortality risk: ametaanalytic review. PLoS Med. 7:e1000316.

Horiuchi M, Endo J, Akatsuka S, Uno T, Hasegawa T, Seko Y. 2013. Influence of forest walking on blood pressure, profile of mood states and stress markers from the viewpoint of aging. J. Aging Gerontol. 1:9-17.

Hunter MD, Eickhoff SB, Pheasant RJ, Douglas MJ, Watts GR, Farrow TFD, Hyland D, Kang J, Wilkinson ID, Horoshenkov KV, Woodruff PWR. 2010. The state of tranquillity: subjective perception is shaped by contextual modulation of auditory connectivity. Neuro Image. 53:611-618.

Insel TR, Young LJ. 2001. The neurobiology of attachment. Nat Rev Neurosci. 2:129-136.

IPCC. 2013. Fifth Assessment Report. Climate Change 2013. Geneva: IPCC.

Jackson LE, Daniel J, McCorkle B, Sears A, Bush KF. 2013. Linking ecosystem services and human health: the Eco-health relationship browser. Int J Public Health. 58:747-755.

Jackson T. 2009. Prosperity without growth. London: Earthscan.

Jacobs M. 2012. Green growth: economic theory and political discourse. Centre for Climate Change Economics. Policy Working Paper no 108.

Jarrett J, Woodcock J, Griffiths UK, Chalabi Z, Edwards P, Roberts I, Haines A. 2012. Effect of increasing active travel in urban England and Wales on costs to the national health service. The Lancet. 379:2198-2205.

Kampman MT, Wilsgaard T, Mellgren SI. 2007. Outdoor activities and diet in childhood and adolescence relate to MS risk above the arctic circle. J Neurol. 254:471-477.

Kanavos P., van den Aardweg S., and Schurer W. 2012. Diabetes expenditure, burden of disease and management in 5 EU countries. LSE Health and Social Care, London School of Economics, London. 
Kaptchuk TJ, Kelley JM, Conboy LA, Davis RB, Kerr CE, Jacobson EE, Kirsch I, Schyner RN, Nam BH, Nguyen LT, et al. 2008. Components of placebo effect: randomised controlled trial in patients with irritable bowel syndrome. BMJ. 336:999-1003.

Kawachi I, Kennedy BP, Lochner K, Prothrow-Smith D. 1997. Social capital, income inequality and mortality. Am J Public Health. 87:1491-1498.

Kiecolt-Glaser JK, Glaser R, Gravenstein S, Malarkey WB, Sheridan J. 1996. Chronic stress alters the immune response to influenza virus vaccine in older adults. Proc Natl Acad Sci. 93:3043-3047.

Krenichyn K. 2004. Women and physical activity in an urban park: enrichment and support through an ethic of care. J Environ Psychol. 24:117-130.

Knapp M, King D, Healey A, Thomas C. 2011. Economic outcomes in adulthood and their associations with antisocial conduct, attention deficit and anxiety problems in childhood. J Mental Health Policy Econ. 14:137-149.

Kubiszewski I, Costanza R, Franco C, Lawn P, Talberth J, Jackson T, Alymer C. 2013. Beyond GDP: measuring and achieving genuine global progress. Ecol Econ. 93:57-68.

Kulkarni S, Levin-Rector A, Ezzati M, Murray C. 2011. Falling behind: life expectancy in US counties from 2000 to 2007 in an international context. Popul Health Metr. 9:1-12.

Kwate NOA, Chun-Yip Y, Loh J-M, Williams D. 2009. Inequality in obesogenic environments: fast food density in New York City. Health Place 15:364-373.

Lachowycz K, Jones AP. 2011. Greenspace and obesity: a systematic review of the evidence. Obes Rev. 12:e183-e189.

Lang T, Rayner G. 2012. Ecological public health: the 21st century's big idea? BMJ. 345:e5466.

Layard R. 2006. Happiness. London: Penguin.

Lee J, Park BJ, Tsunetsugu Y, Ohira T, Kagawa T, Miyazaki Y. 2011. Effect of forest bathing on physiological and psychological responses in young Japanese male subjects. Public Health. 125:93-100.

Louv R. 2005. Last child in the woods. Chapel Hill: Algonquin Press.

Lutz A, Brefczynski-Lewis J, Johnstone T, Davidson RJ. 2008. Regulation of the neural circuitry of emotion by compassion meditation: effects of meditative expertise. PLoS ONE. 3:e1897.

Maas J, Verheij RA, de Vries S, Spreeuwenberg P, Schellevis FG, Groenewegen PP. 2009. Morbidity is related to a green living environment. J Epidemiol Community Health. 63:967-973.

Mapes N, Hine R. 2011. Living with dementia and connecting with nature: looking back and stepping forwards. Chelmsford: Dementia Adventure.

Marmot Review. 2008. Fair society, healthy lives. London: UCL.

McCloughlan P, Batt WH, Costine M, Scully D. 2011. Second european quality of life survey participation in volunteering and unpaid work. Dublin: European Foundation for the Improvement of Living and Working Conditions.

McKibben B. 2007. Deep Economy. New York (NY): Holt.

[MEA] Millennium Ecosystem Assessment. 2005. Ecosystems and human well-being. Washington (DC): Island Press.

Mellor D, Hayashi Y, Stokes M, Firth L, Lake L, Staples M, Chambers S, Cummins R. 2009. Volunteering and its relationship with personal and neighborhood well-being. Nonprof Volunt Sect Quart. 38:144-159.

Mental Health Network. 2011. Key facts and trends in mental health. London (UK): NHS Confederation.

Millard PH, Smith CS. 1981. Personal belonging - a positive effect? Gerontologist. 21:85-90.

Miller G. 2011. Why loneliness is hazardous to your health. Science. 331:138-140.

Mitchell R, Popham F. 2008. Effect of exposure to natural environment on health inequalities: an observational population study. The Lancet. 372:1655-1660.

Mind. 2007. Ecotherapies. London: Mind.

Moore EO. 1982. A prison environment's effect on health care service demands. J Environ Syst. $11: 17-34$

[NSALG] National Society of Allotment \& Leisure Gardeners. 2009. A survey of allotment waiting lists in England. Corby (UK).

Natural England. 2009. An estimate of the economic and health value and cost-effectiveness of the expanded walking for health scheme. Natural England TIN055. Peterborough

Natural England. 2013a. Monitor of engagement with the natural environment (MENE): the national survey on people and the natural environment. London (UK): Natural England. 
NCA. 2014. National climate assessment. Washington (DC)

NEA. 2011. National ecosystem assessment. London: Defra.

[NEF] New Economics Foundation. 2013. Happy planet index. Available from: http://www.happy planetindex.org

Newman P, Matan A. 2012. Human mobility and human health. Curr Opin Environ Sustain. 4:420-426.

NHS. 2010. The economic burden of obesity. London: National Obesity Observatory.

NHS. 2012. Prescription dispersal in the community. Statistics for 2001 to 2011. London (UK): National Health Service.

NICE. 2009. Intervention guidance on workplace health promotion with reference to physical activity. London: NICE.

NY State Health Department. 2014. The obesity problem. Available from: http:/www.health.ny. gov/prevention/obesity/

O’Donnell G, Deaton A, Durand M, Halpern D, Layard R. 2014. Wellbeing and policy. London: Legatum Institute.

OECD. 2011. Towards green growth. Paris: OECD.

OECD. 2013. OECD factbook: economic. Paris: Environmental and Social Statistics.

ONS. 2013. Measuring national well-being - what matters most to personal well-being?. London: Office for National Statistics.

O’Neill DW, Dietz R, Jones N, editors. 2010. Enough is enough. Ideas for a sustainable economy in a world of finite resources. Report of the steady state economy conference. Leeds (UK): Centre for the Advancement of the Steady State Economy and Economic Justice for All.

Parsons R, Tassinary LG, Ulrich RS, Hebl MR, Grossman-Alexander M. 1998. The view from the road: implications for stress recovery and immunization. J Environ Psychol. 18:113-140.

Pencheon D. 2012. People and planet: from vicious cycle to virtuous circle. Brit Med J. 345:9.

PHE. 2013a. Obesity and the environment: Increasing physical activity and active travel. London: Public Health England.

PHE. 2013b. Social and economic inequalities in diet and physical activity. London: Public Health England.

Pitkala KH, Routasalo P, Kautiainen H, Tilva RS. 2009. Effects of psychosocial group rehabilitation on health, use of health care services, and mortality of older persons suffering from loneliness: a randomised, controlled trial. J Gerontol: Med Sci. 64A:792-800.

Poloma MM, Pendleton BF. 1991. The effects of prayer experiences on measures of general well-being. J Psychol Theol. 19:71-83.

Popkin BM. 1998. The nutrition transition and its health implications in lower-income countries. Public Health Nutrit. 1:5-21.

Pratt L, Brody DJ and Gu Q. 2011. Antidepressant use in persons aged 12 and over: US 2005-08. NCHS Brief No 76. Hyattsville (MD): US Department of Health and Human Services.

Pretty J. 1998. The living land. London (UK): Earthscan.

Pretty J. 2003. Social capital and the collective management of resources. Science. 302:1912-1914.

Pretty J. 2013. The consumption of a finite planet: well-being, convergence, divergence and the nascent green economy. Environ Resour Econ. 55:475-499.

Pretty J, Peacock J, Sellens M, Griffin M. 2005. The mental and physical health outcomes of green exercise. Int J Environ Health Res. 15(5):319-337.

Pretty JN, Lang T, Morison J, Ball AS. 2005. Food miles and farm costs: the full cost of the British food basket. Food Policy. 30:1-20.

Pretty J, Barton J, Colbeck I, Hine R, Mourato S, Mackerron G, Wood C. 2011. Health values from ecosystems. Chapter 32. In: National ecosystem assessment. London: Defra; p. 1153-1181.

Price DB, Finniss DG, Benedetti F. 2008. A comprehensive review of the placebo effect: recent advances and current thought. Ann Rev Psychol. 59:565-590.

Putnam R. 1995. Bowling alone: America's declining social capital. J Democracy. 6:65-78.

Ratcliffe E, Gatersleben B, Sowden PT. 2013. Bird sounds and their contributions to perceived attention restoration and stress recovery. J Environ Psychol. 36:221-228.

Rocktrom J, Steffen W, Noone K, Persson A, Chapin FS, Lambin EF, Lenton TM, Scheffer M, Folke C, Shellnhuber HJ, Nykvist B, de Wit CA, Hughes T, van der Leeuw S, Ridhe H, Sorlin S, Snyder PK, Costanza R, Svedin U, Falenmark M, Karlberg L, Correll RW, Fabry VJ, 
Hansen J, Walker B, Liverman D, Richardson K, Crutzen P, Foley JA. 2009. Planetary boundaries: exploring the safe operating space for humanity. Ecol Soc. 14:32.

Roe JJ, Ward Thompson C, Aspinall PA, Brewer MJ, Duff EI, Miller D, Mitchell R, Clow A. 2013. Green space and stress: evidence from cortisol measures in deprived urban communities. Int J Environ Res Public Health. 10:4086-4103.

Royal Society. 2012. People and the planet. London: Royal Society.

Rutt CD, Coleman KJ. 2005. The impact of the built environment on walking as a leisure-time activity along the US/Mexico border. J Phys Activity Health. 3:257-271.

Rystedt LW, Cropley M, Devereux JJ, Michalianou G. 2008. The relationship between long-term job strain and morning and evening saliva cortisol secretion among white-collar workers. J Occup Heal Psychol. 13:105-113.

Sandlund ES, Norlander T. 2000. The effects of Tai Chi Chuan relaxation and exercise on stress responses and well-being: an overview of research. Int J Stress Manage. 7:139-149.

Schultz SE, Kleine RE, Kernan JB. 1989. "These are a few of my favourite things". Toward an explication of attachment as a consumer behavior construct. Adv Consumer Res. 16:359-366.

Schultz-Kleine S, Baker SM. 2004. An integrative review of material possession attachment. Acad Market Sci Rev. 1:1-35.

Shapiro SL, Oman D, Thoresen CE, Plante TG, Flinders T. 2008. Cultivating mindfulness: effects on well-being. J Clin Psychol. 64:840-862.

Sherman E, Newman ES. 1977. The meaning of cherished personal possessions for the elderly. J Aging Human Develop. 8:181-192.

Smoyer-Tomic KE, Spence JC, Raine KD, Amrhein C, Cameron N, Yasenovsky V, Cutumisu N, Hemphill E, Healy J. 2008. The association between neighbourhood socioeconomic status and exposure to supermarkets and fast food outlets. Health Place. 14:740-754.

Sport England. 2014. Active people survey. Available from www.sportengland.org

Sternberg E. 2009. Healing spaces. Cambridge (MA): Harvard University Press.

Strathearn L, Fonagy P, Amico J, Montague PR. 2009. Adult attachment predicts maternal brain and oxytocin response to infant cues. Neuropsychopharmacology. 34:2655-2666.

Takano T, Nakamura K, Watanabe M. 2002. Urban residential environments and senior citizens' longevity in megacity areas: the importance of walkable green spaces. J Epidemiol Community Health. 56:913-918.

Tearfund. 2007. Churchgoing in the UK. Teddington (UK): Tearfund.

Terrapin Bright Green. 2012. The economics of Biophilia. Why designing with nature in mind makes financial sense. New York (NY): Terrapin Bright Green.

Telema R, Yang X, Viikari J, Valimaki I, Wanne O, Raitakari O. 2005. Physical activity from childhood to adulthood: a 21-year tracking study. Am J Prevent Med. 28:267-273.

Thoits PA, Hewitt LN. 2001. Volunteer work and well-being. J Health Soc Behav. 42:115-131.

Thompson Coon J, Boddy K, Stein K, Whear R, Barton J, Depledge MH. 2011. Does participating in physical activity in outdoor natural environments have a greater effect on physical and mental wellbeing than physical activity indoors? A systematic review. Environ Sci Technol. doi:10.1021/es102947t.

Trubka R, Newman P, Bilsborough D. 2010. Costs of urban sprawl (3): physical activity links to healthcare costs and productivity. Environ Design Guide 85:1-13.

Tuan Y-F. 1977. Sense and Place. Minneapolis (MN): University of Minnesota Press.

Tudor-Locke C, Bassett DR. 2004. How many steps per day are enough? Sports Med. 34:1-8.

Ulrich RS. 1984. View through a window may influence recovery from surgery. Science 224: $420-421$.

UCS. 2014. The $\$ 11$ trillion reward how simple dietary changes can save lives and money, and how we can get there. Cambridge (MA): Union of Concerned Scientists.

UNCSD. 2012. United Nations Conference on Sustainable Development. Available from: http:// www.uncsd2012.org/rio20/

UNDP. 2011. Human development report 2011 - sustainability and equity. New York (NY): UNDP.

UNEP. 2011. Towards a green economy: pathways to sustainable development and eradication of poverty. Nairobi: UNEP.

UNICEF. 2012. Levels and trends in child mortality. New York (NY): UNICEF.

USDA ERS. 2013. Food availability (per capita) data system. Available from: www.ers.usda.gov/ data-products 
Veenhoven R. 2012. Trends in nations. World database of happiness: Erasmus University Rotterdam. Available from: www.worlddatabaseofhappiness.eur.nl.

Walker S. 2011. The spirit of design. London: Earthscan.

Wang LY, Denniston M, Lee S, Galuska D, Lowry R. 2010. Long-term health and economic impact of preventing and reducing overweight and obesity in adolescence. J Adolescent Health. 46:467-473.

Wapner S, Demick J, Redondo JP. 1990. Cherished possessions and adaptation of older people to nursing homes. Int J Aging Human Develop. 31:219-235.

Ward Thompson C, Roe J, Aspinall R, Mitchell R, Clow A, Miller D. 2012. More green space is linked to less stress in deprived communities: Evidence from salivary cortisol patterns. Landscape Urban Plan. 105:221-229.

Wells N, Lekies KS. 2006. Nature and the life course: pathways from childhood nature experiences to adult environmentalism. Children, Youth Environ. 16:1-24.

Wheeler BW, White M, Stahl-Timmins W, Depledge MH. 2012. Does living by the coast improve health and wellbeing? Health Place. 18:1198-1201.

White M, Smith A, Humphryes K, Pahl S, Snelling D, Depledge M. 2010. Blue space: the importance of water for preference, affect, and restorativeness ratings of natural and built scenes. J Environ Psychol. 30:482e493.

WHO. 2004. World health report. Geneva: WHO.

WHO. 2010. Global recommendations on physical activity for health. Geneva: WHO.

Wichstrom L, von Soest T, Kvalem IL. 2013. Predictors of growth and decline in leisure time in physical activity from adolescence to adulthood. Health Psychol. 32:775-784.

Wijlaars LPM, Nazareth I, Whitaker HJ, Evans S, Petersen I. 2003. Suicide-related events in young people following prescription of SSRIs and other antidepressants. BMJ Open. 3: e003247.

Williams M, Penman D. 2011. Mindfulness London: Pitakus.

Windle K, Francis J, Coomber C. 2011. Preventing loneliness and social isolation: interventions and outcomes. Social Care Institute for Excellence Research Briefing 39. London.

World Bank. 2012. Inclusive green growth. Washington (DC): The pathway to sustainable development.

WWF. 2010. Living planet report. London and Oakland: WWF and Global Footprint Network.

Zak PJ, Stanton AA, Ahmadi S. 2007. Oxytocin increases generosity in humans. PLoS ONE. 2: e1128.

Zubieta J-K, Stohler CS. 2009. Neurobiological mechanisms of placebo responses. Ann NY Acad Sci. 1156:198-210. 